\title{
Absence of a gastrin inhibitory factor in the IgG fraction of serum from patients with pernicious
} anaemia

\author{
J T L Smith, A Garner, S E Hampson, R E Pounder
}

\begin{abstract}
Patients with Addisonian pernicious anaemia are alleged to generate antibodies directed against the gastrin receptor. We purified IgG from 15 patients with pernicious anaemia and 15 healthy controls in an effort to show attenuation of gastrin specific binding in vitro and inhibition of gastrin stimulated acid secretion in vivo. Binding of the IgG fraction was determined in a radioreceptor assay utilising the rat pancreatic carcinoma cell line AR42J which expresses high affinity gastrin binding sites $\left(K_{d}=5 \times 10^{-10}\right)$. In comparison with control serum, there was no significant displacement $(p=0 \cdot 10)$ of human gastrin-17 binding by pernicious anaemia samples at either $0.3 \mathrm{mg}$ protein/ml (control (mean (SEM)) 1489 (131) cpm; patients 1858 (174) cpm) or 3 mg protein/ ml (control 1930 (110); patients 2195 (107) cpm). The effect of intravenous and intragastric IgG on acid secretion in the anaesthetised rat was determined over a 60 minute period after stimulation with $1 \mu \mathrm{g} / \mathrm{kg}$ human gastrin-17. A bolus injection of IgG (60-200 $\mathrm{mg} / \mathrm{kg})$ had no significant effect $(p=0.50)$ on gastrin stimulated acid output (29.21 (1.28) $\mu \mathrm{mol} \mathrm{\textrm {H } ^ { + } / \mathrm { h } )}$ compared with control (27.48 (4.70) $\mu \mathrm{mol}$ $\left.\mathrm{H}^{+} / \mathrm{h}\right)$. Similarly, instillation of $800 \mathrm{mg} / \mathrm{kg} \mathrm{IgG}$ directly into the stomach for 90 minutes also failed to influence gastrin stimulated acid output $\left(29.69(3.22) \mu \mathrm{mol} \mathrm{H}^{+} / \mathrm{h}\right)$. Thus, we have been unable to confirm previous reports of an IgG from patients with pernicious anaemia capable of blocking gastrin receptor binding or gastrin stimulated acid secretion.
\end{abstract}

Animal studies have shown that hypergastrinaemia induced by longterm treatment with omeprazole or potent $\mathrm{H}_{2}$ antagonists causes hyperplasia of the enterochromaffin-like cells present in the gastric mucosa which may eventually develop into carcinoid tumours. ${ }^{1-6}$ Addisonian pernicious anaemia causes longterm achlorhydria and hypergastrinaemia in humans, and it is also associated with enterochromaffinlike cell hyperplasia and carcinoids. ${ }^{7}$ The degree of hypergastrinaemia associated with pernicious anaemia has been estimated at between 6 and 136 times the normal range..$^{8-12}$ A comparative study has shown that the median integrated 24 hour plasma gastrin concentration was 34 -fold higher in patients with pernicious anaemia than healthy volunteers. ${ }^{13}$ Although there is a significant inverse correlation between intragastric acidity and plasma gastrin concentration during the administration of antisecretory drugs, ${ }^{14}$ is the most potent antisecretory regimen tested in duodenal ulcer patients (omeprazole $20 \mathrm{mg}$ daily for 28 days) caused only a four fold rise of integrated $24 \mathrm{~h}$ plasma gastrin concentration. Comparison of this finding with the hypergastrinaemia prevailing in patients with pernicious anaemia suggests that drug induced hypergastrinaemia is unlikely to result in enterochromaffin-like hyperplasia or carcinoid tumours at therapeutic dose concentrations in humans. ${ }^{1314}$

There is, however, a potential problem with using pernicious anaemia as a model to predict the consequences of prolonged hypergastrinaemia in humans. Thus two studies have reported that the serum of some patients with pernicious anaemia contains an IgG antibody directed against the gastrin receptor which is capable of antagonising gastrin stimulated parietal cell secretion in vitro. ${ }^{16} 17$ Such an antibody could conceivably exert a protective effect in patients with pernicious anaemia by also blocking the trophic action of gastrin on enterochromaffin-like cells. Therefore, despite high plasma concentrations, the biological activity of gastrin would be neutralised and hypergastrinaemia associated with pernicious anaemia would be an inappropriate model for comparison with drug induced hypergastrinaemia. The object of this study was to confirm or refute the presence of an antigastrin receptor antibody in the serum of patients with pernicious anaemia. Two systems were used to investigate inhibition of gastrin activity: an in vitro gastrin radioreceptor assay and an in vivo acid secretion model using the anaesthetised rat.

\section{Methods}

PATIENT DATA AND IgG PURIFICATION

A $60 \mathrm{ml}$ sample of venous blood was taken from 15 patients with pernicious anaemia (age range 37-78 years) and 15 healthy control subjects (age range 21-66 years). All patients were gastric parietal cell antibody positive at a titre of $>1: 40$ and all had an abnormal Schilling test for vitamin B-12 absorption.

Blood was centrifuged at $3000 \mathrm{rpm}$ for $15 \mathrm{~min}$ and the serum stored at $-20^{\circ} \mathrm{C}$. IgG was fractionated by the Rivanol/ammonium sulphate precipitation method described previously. ${ }^{18}$ The presence and purity of IgG were determined by immunodiffusion against rabbit antihuman IgG and antihuman sera antibodies (DAKOImmunoglobulins, Denmark). Only a single preciptin line corresponding to IgG was observed. Protein concentration was determined in each sample by colorimetic assay (Bio-Rad, 
Munich, W Germany). After completion of the experiments described below, the antibody activity of each IgG fraction was assessed again; all repeat gastric parietal cell antibody tests were positive except one.

IN VITRO GASTRIN RADIORECEPTOR ASSAY

A rat pancreatic carcinoma cell line (AR42J), which displays high affinity gastrin binding sites $\left(K_{d}=5 \times 10^{-10} M\right)$, was grown in Rosewell Park Memorial Institute medium with $10 \%$ fetal calf serum and glutamine. Cells were seeded 48 hours before use in 24 well plates at a density of $3.5 \times 10^{5}$ cells per well in a volume of $200 \mu \mathrm{l}$. The growth medium was aspirated and the monolayer washed twice with $0.5 \mathrm{ml}$ of assay buffer ( $7 \cdot 8 \mathrm{~g}$ Earle's balanced salts without bicarbonate, $50 \mathrm{mM}$ HEPES, $0 \cdot 1 \%$ bovine serum albumin, 1 part per 100 of aprotinin; adjusted to $\mathrm{pH} 7$ ).

Four replicate wells per plate were used to obtain total binding after the addition of $100 \mu \mathrm{l}$

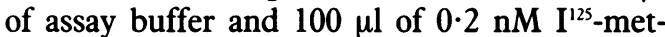
human gastrin-17 (I ${ }^{125}$ HG-17). Non-specific binding was determined in a further four wells after the addition of $100 \mu \mathrm{l}$ of $2 \mu \mathrm{M}$ unlabelled human gastrin-17 (HG-17). The remaining 16 wells per plate were used to assess binding in the presence of IgG by adding $100 \mu \mathrm{l}$ of $0.2 \mathrm{nM}^{125}$ HG-17 and $100 \mu \mathrm{l}$ of IgG at a protein concentration of either $0.3 \mathrm{mg}$ or $3 \mathrm{mg} / \mathrm{ml}$. The plates were incubated for 45 minutes at room temperature and then washed three times in ice cold phosphate buffered saline. Cells were lysed by the addition of $1 \mathrm{ml}$ of $0 \cdot 1 \mathrm{M} \mathrm{NaOH}$ containing $2 \%$ sodium carbinate and $1 \%$ sodium dodecyl sulphate. The lysate was then counted for 60 seconds in a gammacounter. All samples - 15 from patients with pernicious anaemia and 15 from control subjects - were studied in duplicate at both protein concentrations.

\section{IN VIVO ANTISECRETORY ASSAY}

Female Alderley Park strain rats (200-260 g) were fasted overnight with free access to water. Anaesthesia was induced and maintained by intramuscular injection of urethane $(1.5 \mathrm{~g} / \mathrm{kg})$. Body temperature was maintained at $36-37^{\circ} \mathrm{C}$ by a rectal thermistor and thermostatically controlled heated table. The trachea and an external jugular vein were cannulated, and then a multiorifice orogastric tube was introduced into the proximal portion of the stomach. After laparotomy, a short length of rigid polyethylene tubing was inserted into the antrum through an incision in the duodenum and exteriorised via the flank. The stomach was perfused by means of the orogastric tube with saline at $7 \mathrm{ml} / \mathrm{min}$ and collected at $10 \mathrm{~min}$ intervals from the pyloric outlet. Samples were titrated with $0.1 \mathrm{~m} \mathrm{NaOH}$ to an end point of $\mathrm{pH} 6.4$ and acid output

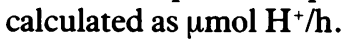

Basal acid output was recorded for $30 \mathrm{~min}$, then secretion was stimulated by intravenous injection of $1 \mu \mathrm{g} / \mathrm{kg} \mathrm{HG-17}$. This control response was followed $90 \mathrm{~min}$ later by injection of either control IgG samples or patient IgG samples in a dose volume of $2 \mathrm{ml} / \mathrm{kg}$ containing a protein concentration of $30-100 \mathrm{mg} / \mathrm{ml}$. After a further $10 \mathrm{~min}$ a second identical dose of HG-17 was given and acid output monitored for a further $60 \mathrm{~min}$. A second series of experiments was performed in which IgG from eight of the patients with pernicious anaemia was administered directly into the rat stomach. Perfusion was interrupted $60 \mathrm{~min}$ after the first gastrin injection and the stomach filled with a $2.5 \mathrm{ml}$ sample containing $800 \mathrm{mg}$ protein $/ \mathrm{ml}$. After 90 $\mathrm{min}$, the sample containing IgG was removed, gastric perfusion restarted, and a second gastrin response was obtained.

Each IgG fraction from patients was tested in quadruplicate (intravenous) or duplicate (intragastric) to obtain the individual mean values. Control fractions $(n=15)$ were tested in one rat per sample.

\section{Results}

Specific binding of $\mathrm{I}^{125} \mathrm{HG}-17$ at both IgG concentrations is shown in Figure 1 for the 15 healthy control subjects and 15 patients with pernicious anaemia. Mean (2 SEM) binding at $0.3 \mathrm{mg} / \mathrm{ml}$ was 1489 (131) counts per minute (cpm) for control subjects and 1858 (174) cpm for the patients. At $3 \mathrm{mg}$ protein $/ \mathrm{ml}$, values were 1930 (110) cpm and 2195 (107) for control subjects and patients respectively. Analysis of these data by Student's unpaired $t$ test showed no significant difference $(p>0 \cdot 1)$ between patients and control subjects at either protein concentration.

Gastrin induced a submaximal four fold increase of acid output in the anaesthetised rat at a dose of $1 \mu \mathrm{g} / \mathrm{kg}$ intravenously. The response showed little or no tachyphylaxis after a second dose of gastrin. Thus comparison of the first and second responses (peak or AUC) provides a convenient model for detecting gastrin antagonist activity in vivo. Figure 2 compares overall mean acid output in rats dosed intravenously with IgG isolated from volunteers or patients with pernicious anaemia. It is clear that there is no difference between these two groups

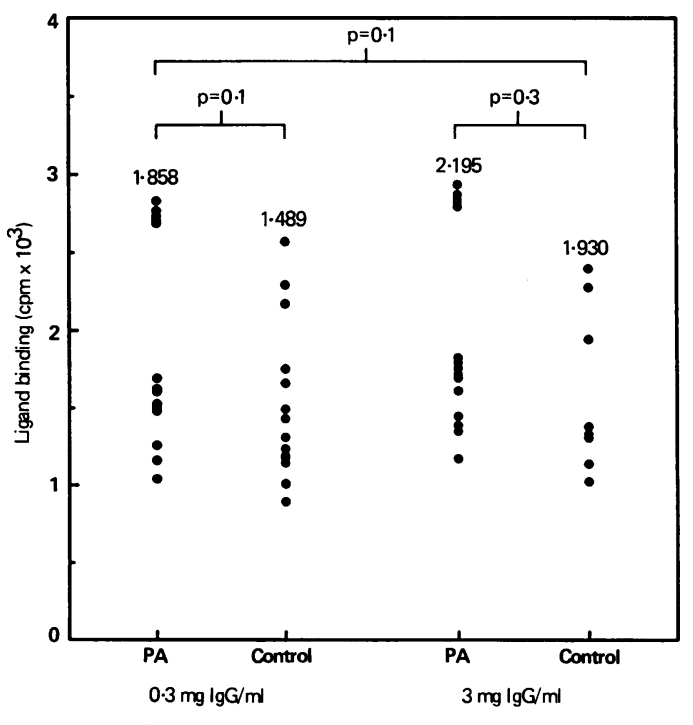

Figure 1: Effect of IgG from patients with pernicious anaemia $(P A)$ and healthy control subjects on binding of $I^{125}$ human gastrin-17 to receptors on the rat pancreatic cell line $A R 42 \mathcal{f}$ at two IgG concentrations $(0.3$ and $3 \mathrm{mg} / \mathrm{ml})$. Mean values are shown for each set of data points. 


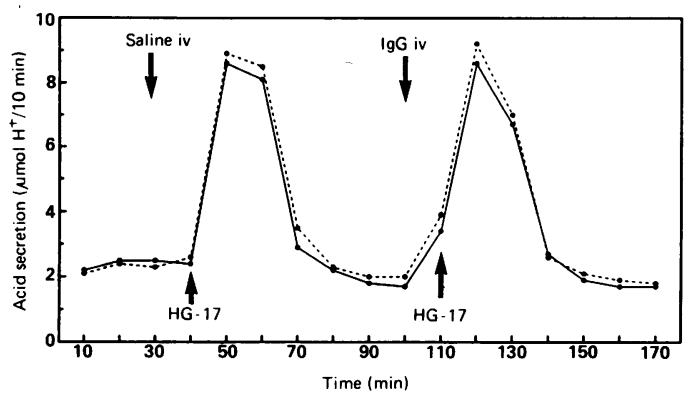

Figure 2: Effect of IgG from control subjects and patients with pernicious anaemia on acid secretory responses in the perfused rat stomach preparation stimulated by human gastrin-17 at $1 \mu \mathrm{g} / \mathrm{kg}$ intravenously. Overall mean values are shown $(n=15$ for each group). There was no significant difference $(p>0 \cdot 10)$ between the two curves at any data point.

$(0.5<\mathrm{p}<0.7$ by one way analysis of variance). Injection of human IgG induced a slight increase in acid secretion in the rat but the effect was identical for control and pernicious anaemia samples.

Integrated acid output in response to the second dose of gastrin is shown for individual IgG samples in Figure 3. It is equally clear that neither intravenous $\left(29(1.0) \mu \mathrm{mol} \mathrm{H}^{+} / \mathrm{h}\right)$ nor

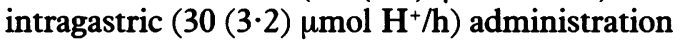
of $\mathrm{IgG}$ from patients with pernicious anaemia influenced gastrin stimulated acid output when compared with a corresponding control group $(28(2 \cdot 4) \mu \mathrm{mol} / \mathrm{h})$.

\section{Discussion}

A previous study reported the presence of an antigastrin receptor antibody in the serum of about $50 \%$ of patients with pernicious anaemia as detected by inhibition of gastrin stimulated aminopyrine uptake by isolated rodent parietal cells. ${ }^{16} \mathrm{~A}$ second study has reported inhibition of basal acid secretion by bullfrog fundic mucosa and inhibition of gastrin stimulated carbonic anhydrase activity assessed in a cytochemical assay. ${ }^{17}$ One further report has described the

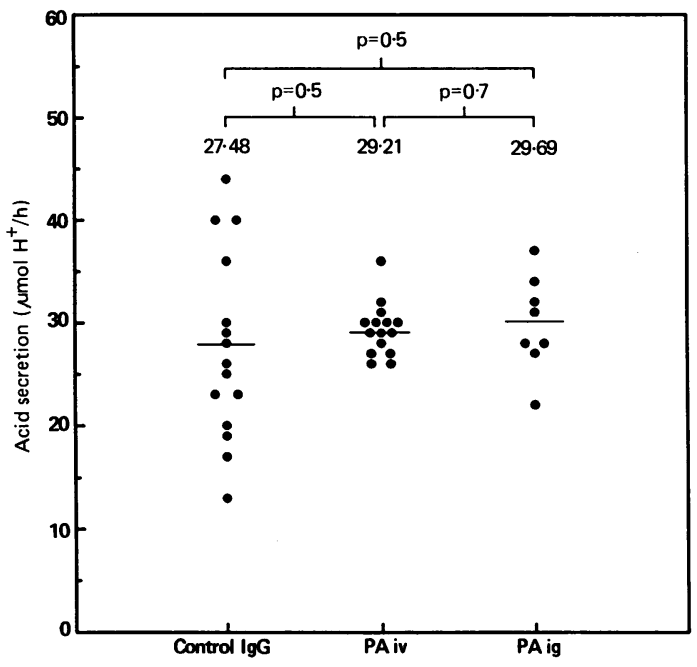

Figure 3: Effect of IgG from control subjects and patients with pernicious anaemia $(P A)$ on integrated acid output from the perfused rat stomach stimulated by human gastrin-17 at $1 \mu \mathrm{g} /$ $\mathrm{kg}$ intravenously. Samples from patients were tested after intravenous injection of 60-200 $\mathrm{mg}$ protein/ $\mathrm{kg}$ and intragastric instillation of $80 \mathrm{mg} / \mathrm{kg}$ (ig). Mean values are shown for each set of data points. presence of an antibody against the gastrin receptor in a proportion of patients with pernicious anaemia as determined from binding studies in an enriched parietal cell preparation from rat gastric mucosa. ${ }^{19}$

The experiments reported in the present paper did not confirm the presence of an antigastrin receptor antibody in the IgG fraction of serum from any of the 15 patients with pernicious anaemia. Although extraction of immunoglobulin from whole serum was necessary to separate the IgG from endogenous gastrin, this procedure left functional parietal cell antibody in 14 of 15 samples as assessed by indirect immunofluorescence. No antigastrin activity was detected in terms of either an interaction with a gastrin receptor or in an in vivo assay system. The gastrin receptor on the AR42J cells (a rat pancreatic tumour line) is linked to growth as evidenced by the ability of gastrin to stimulate ornithine decarboxylase activity. ${ }^{20}$ Furthermore, antagonists of gastrin which interact with this binding site also antagonise gastrin stimulated acid secretion (Garner and Woodburn, unpublished observations). Thus inhibition of gastrin stimulated acid secretion provides a valid approach for detecting antagonists of the trophic actions of gastrin.

The old adage of 'proving a negative result' remains one of the most difficult problems for this study. In the present context, it is conceivable that the rat gastrin receptor fails to recognise an antibody directed against the human receptor. Gastrin sequences, however, are highly conserved across species and little variation exists with respect to receptor binding affinities, suggesting that an autoantibody to the active site of the human gastrin receptor would intereact with that of the rat. Furthermore, previous studies showing inhibition of the action of gastrin by human gastric parietal cell antibody have also used rodent tissue in addition to tissue from bullfrog, guinea pig, and dog. ${ }^{16} 1721$ Another constituent in pernicious anaemia serum may be responsible for attenuation of acid secretion in those previous studies which have reported an inhibitory effect. It is therefore interesting that serum from patients with pernicious anaemia displays cytotoxicity ${ }^{22}$ and hence may act via complement fixation or by a direct antibodydependent cell-mediated cytotoxic action on the parietal cell rather than via the gastrin receptor.

A recently published study ${ }^{21}$ has also failed to detect gastrin receptor antibody activity in immunoglobulin fractions of serum from 17 patients with pernicious anaemia utilising a radioreceptor assay to measure ${ }^{125} I$ gastrin binding in a guinea pig gastric mucosal cell suspension. The same study, however, showed that immunogloblin fractions from patients with pernicious anaemia inhibited the activity of $\mathrm{H}^{+}$, $\mathrm{K}^{+}$-ATPase in a tubulovesicular membrane preparation from porcine gastric mucosa. Although inhibition of this ultimate step in acid secretion would antagonise the action of gastrin, our study failed to show activity in vivo after either parenteral or intragastric administration of the IgG fraction. In the latter case, instillation of a high concentration of IgG into the lumen of the stomach would allow direct access of the 
antibody to the $\mathrm{H}^{+}$transport enzyme by simple diffusion into the gastric glands.

We thank Mrs B Curry, Miss J Gilroy, Miss E Monk, Mrs A Stanier, and Mr J Woodburn for their help with this study, and Miss D Elliott and Miss A Wright for secretarial help.

1 Larsson H, Carlsson E, Mattsson $\mathrm{H}$, et al. Plasma gastrin and gastrin entero-chromaffin-like cell activation and prolifeagastrin entero-chromaffin-like cell activ
tion. Gastroenterology 1986; 90 : 391-9.

2 Hirth RS. ECL cell proliferation and neoplasia associated with $\mathrm{H}_{2}$-receptor antagonist BL-6341. Toxicol Pathol 1987; 15: $364-5$.

3 Streett CS, Robertson FL, Crissman IJ. Morphological stomach findings in rats and mice treated with $\mathrm{H}_{2}$-receptor antagonists ICI 125211 and ICI 162846. Toxicol Pathol 1987; 15: 364-5.

4 Harleman JH, Betton GR, Dormer C, McCrossan M. Gastric neuroendocrine hyperplasia after treatment with the longacting potent $\mathrm{H}_{2}$-antagonist SKF 93479. Scand $\mathcal{f}$ Gastroacting potent $\mathrm{H}_{2}$-antagon
enterol $1987 ; 22$ : 595-600.

5 Arnold R, Koop H, Schwarting H, Tuch K, Willemer B. Effect of acid inhibition on gastric endocrine cells. Scand $\dot{\mathcal{J}}$ Gastroenterol 1986; 21: 14-9.

6 Blom H. Alterations in gastric mucosal morphology induced by long-term treatment with omeprazole in rats. Digestion 1986; 35: 98-105.

7 Borch K, Renvall H, Liedburg G, Andersen BN. Relations between circulating gastrin and endocrine cell proliferation in the atrophic gastric fundic mucosa. Scand $\mathcal{F}$ Gastroenterol 1986; 21: 357-63.

8 Larsson LI, Rehfeld JF, Stockbrugger RW, et al. Mixed endocrine gastric tumours associated with hypergastrinaemia of antral origin. Am 7 Pathol 1978; 93: 53-68.

9 Capella C, Polak J, Timson CM, Frigerio B, Solcia E. Gastric carcinoids of agyrophic ECL cells. Ultrastruct Methodol carcinoids of $1980 ; 1: 411-8$.

10 Harvey RF, Bradshaw KN, Davidson CM, Wilkinson SP, Davies PS. Multifocal gastric carcinoid tumours, achlorhydria, and hypergastrinaemia. Lancet 1985; i: 951-3.
11 Borch K, Renvall H, Liedburg G. Gastric endocrine cell hyperplasia and carcinoid tumours in pernicious anemia. Gastroenterology 1985; 88: 638-48.

12 Carney JA, Go VLW, Fairbanks VF, Breanndan-Moure S Alport E, Nora FE. The syndrome of gastric argyrophil carcinoid tumors and non-antral gastric atrophy. Ann Intern Med 1983; 99: 761-6.

13 Lanzon-Miller S, Pounder RE, Hamilton MR, et al. Twentyfour-hour intragastric acidity and plasma gastrin concentrafour-hour intragastic acidity and plasma gastrin concentraulcer, or pernicious anaemia. Aliment Pharmacol Therap ulcer, or pernicio

14 Lanzon-Miller S, Pounder RE, Hamilton MR, et al. Twentyfour-hour intragastric acidity and plasma gastrin concentration before and during treatment with either ranitidine or omeprazole. Aliment Pharmacol Therap 1987; 1: 239-51.

15 Pounder RE, Smith JTL. Drug-induced changes of plasma gastrin. Gastroenterol Clin North Am 1990; 19: 141-53.

16. de Aizpurua HJ, Ungar B, Toh B-H. Serum from patients with pernicious anaemia blocks gastrin stimulation of acid secretion by parietal cells. Clin Exp Immunol 1985; 61: 31522.

17 Loveridge $\mathrm{N}$, Bitensky $\mathrm{L}$, Chayen $\mathrm{J}$, et al. Inhibition of parietal cell function by human gammaglobulin containing parietal cell function by human gammaglobulin containing gastric pari

18 Horejsi J, Smetana R. The isolation of gammaglobulins from blood serum by Rivanol. Acta Med Scand 1956; 155: 65.

19 de Aizpurua JH, Ungar B, Toh BH. Autoantibody to the gastrin receptor in pernicious anemia. $N$ Engl $\mathcal{F}$ Med 1985; 13: 479-84.

20 De Vries L, Scemama JL, Pradayrol L, Ribet A. CCK-gastrin peptides stimulate ornithine decarboxylase activity in the pancreatic AR42J cell line. In: Bali J-P, Martinez J, eds. Gastrin and cholecystokinin. Amsterdam: Elsevier, 1987: 111-4.

21 Burman P, Mardh S, Norberg L, Karlsson FA. Parietal cell antibodies in pernicious anemia inhibit $\mathrm{H}^{+}, \mathrm{K}^{+}$-adenosine triphosphatase, the proton pump of the stomach. Gastrotriphosphatase, the proton
enterology 1989; 9 : 1434-8.

22 de Aizpurua JH, Cosgrove LH, Ungar B, Toh BH. Autoantibodies cytotoxic to gastric parietal cells in serum of patients with pernicious anaemia. N Englf Med 1983; 309: 625-9. 